\title{
ANALISIS PERBAIKAN TANAH SEBAGAI BENTUK MITIGASI BENCANA LIKUIFAKSI YANG DAPAT DIAPLIKASIKAN MASYARAKAT DI PALU
}

\author{
David Manoel Mangunpraja ${ }^{1}$, dan Aniek Prihatiningsih ${ }^{2}$ \\ ${ }^{1}$ Program Studi Sarjana Teknik Sipil, Universitas Tarumanagara, Jl. Letjen S. Parman No.1 Jakarta \\ Email: david.manoel84@gmail.com \\ ${ }^{2}$ Program Studi Sarjana Teknik Sipil, Universitas Tarumanagara, Jl. Letjen S. Parman No.1 Jakarta \\ Email: aniekp@ft.untar.ac.id
}

\begin{abstract}
ABSTRAK
Likuifaksi dapat terjadi ketika tanah jenuh atau sebagian jenuh secara substansial kehilangan kekuatan dan kekakuan akibat adanya gempa bumi atau goncangan mendadak, disertai perubahan material yang bersifat padat (solid) menjadi seperti cairan (liquid). Pada insiden di Palu tanah secara tiba-tiba tengelam menjadi larutan air kemudian bergeser seakan-akan berjalan sendiri. Berdasarkan data yang diperoleh korban bencana likuifaksi di Palu, ada 2.256 orang yang meninggal, 1.309 orang hilang, 4.612 orang terluka (Kepala Pusat Data Informasi dan Humas BNPB, Sutopo Purwo Nugroho). Banyak korban jiwa yang meninggal akibat peristiwa tersebut. Jumlah korban yang signifikan, menimbulkan pertanyaan apakah mungkin likuifaksi adalah hal baru di dunia teknik sipil. Ternyata sudah banyak yang melakukan penelitian mengenai likuifaksi. Apa mungkin likuifaksi tidak memiliki solusi? Karena masalah ini terus menerus terjadi terutama di Indonesia.. Skripsi ini akan menjelaskan mengenai likuifaksi dan bagaimana cara memperbaiki tanah likuifaksi dengan cara yang sederhana. Apakah masyarakat umum mengaplikasikannya? Tentu saja bisa, karena likuifaksi bukanlah sesuatu hal yang membahayakan dan dapat diatasi dengan cara yang tepat. Beberapa solusi sederhana yang bisa diaplikasikan masyarakat adalah: Micropile Bambu, Tanaman Baobab, Piezometer, Sumur Biopori.
\end{abstract}

Kata kunci: Likuifaksi, Micropile Bambu, Tanaman Baobab, Piezometer,Sumur Biopori

\section{PENDAHULUAN}

\section{Latar Belakang}

Likuifaksi merupakan peristiwa meningkatnya tekanan air pori tanah akibat tegangan siklik dalam getaran tanah yang diakibatkan oleh gempa. Likuifaksi merupakan gejala peluluhan pasir lepas yang bercampur dengan air akibat goncangan gempa dimana gaya pemicu melebihi gaya yang dimiliki oleh litologi setempat dalam menahan guncangan. Hal ini bisa menyebabkan beberapa kejadian seperti penurunan cepat (quick settlement), fondasi bangunan menjadi miring (tilting) atau penurunan sebagian (differential settlement), dan mengeringnya air sumur yang tergantikan oleh material non kohesif.Likuifaksi merupakan bencana yang bisa merusak kondisi infrastruktur sehingga pengetahuan terhadap potensi dan kerawanan likuifaksi sangat penting terutama dalam merencanakan tata ruang khususnya di daerah Palu dan sekitarnya. Pengetahuan likuifaksi harus juga diberikan bagi warga Palu. Pengetahuan tersebut berupa pengetahuan mitigasi sederhana yang mampu diaplikasikan pada oleh warga sekitar Palu. Oleh sebab itu tujuan penelitian Ini adalah mengetahui Potensi Likuifaksi dan memperkirakan sampai kedalaman berapa likuifaksi itu terjadi berdasarkan data tanah yang ada dan memberikan mitigasi bencana likuifaksi dengan cara yang mudah diaplikasikan oleh masyarakat. Sehingga bermanfaat untuk masyarakat Palu, diharapkan dapat memberkan usulan perbaikan yang mampu membantu masyarakat Palu dalam mempertimbangkan upaya untuk mengatasi permasalahan likuifaksi yang terjadi, serta diharapkan mendapat inspirasi dan ilmu pengetahuan yang dapat digunakan sebagai bahan refrensi bagi penelitian sejenis yang akan dilakukan ataupun diaplikasikan sebagai metode perbaikan tanah di daerah lain.

\section{LANDASAN TEORI}

\section{Percepatan Gempa (amax)}

Gempa bumi adalah getaran yang terjadi di permukaan bumi akibat pelepasan energi dari dalam secara tiba-tiba yang menciptakan gelombang seismik. Palu merupakan salah Satu daerah rawan bencana gempa bumi dan likuifaksi di Indonesia. Dari beberapa pemantauan yang dilakukan oleh para ahli, terdapat beberapa kasus likuifaksi yang terjadi di beberapa daerah di Palu. Untuk itu sangat penting untuk menganalisis potensi likuifaksi di daerah palu agar aman terhadap bahaya likuifaksi apabila terjadi gempa besar.Percepatan gempa di batuan dasar dapat dihitung dengan melihat 
gambar Wilayah Gempa di Indonesia dengan percepatan puncak batuan dasar dengan periode ulang 500 tahun (SNI 031726-2002).

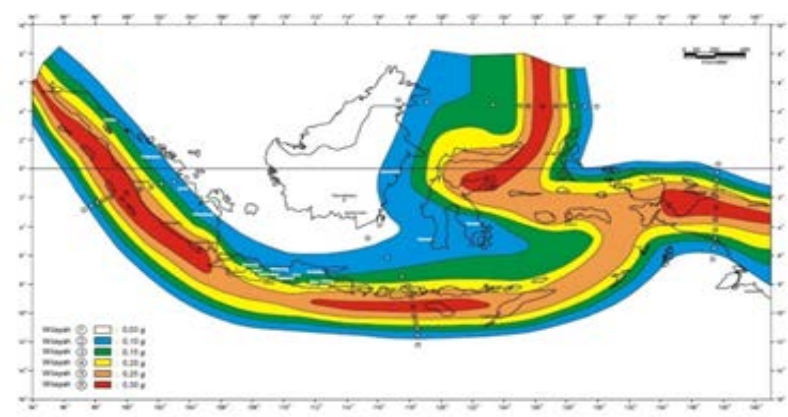

Gambar 1. Wilayah Gempa di Indonesia dengan percepatan puncak batuan dasar dengan periode ulang 500 tahun (SNI 03-1726-2002).

\section{Percepatan Gempa di Permukaan Tanah}

Perubahan percepatan gempa di batuan dasar akan berpengaruh langsung pada percepatan gempa di permukaan tanah.perubahan tersebut dapat dilihat di SNI 03-1726-2002 “Tata Cara Perencanaan Ketahanan Gempa Untuk Bangunan Gedung”

\section{Likuifaksi}

Likuifaksi adalah proses berkurangnya kekuatan geser tanah akibat beban seismik ketika terjadi gempa bumi. Menurut Towhata (2008) likuifaksi terjadi pada tanah yang berpasir lepas (tidak padat) dan jenuh air. Kondisi ini dapat dinyatakan sebagai berikut :

$$
\sigma^{\prime}=\sigma-\mathrm{u}
$$

dengan $\sigma^{\prime}=$ tegangan efektif, $\sigma=$ tegangan total (berat permukaan tanah) , $\mathrm{u}=$ tekanan air pori

Seed et al (1975) menyatakan bahwa likuifaksi adalah proses perubahan kondisi tanah pasir yang jenuh air menjadi cair akibat meningkatnya tekanan air pori yang harganya menjadi sama dengan tekanan total oleh sebab terjadinya beban dinamik, sehingga tegangan efektif tanah menjadi nol. Menurut Wang dan Law (1994) faktor-faktor yang mempengaruhi terjadinya likuifaksi dapat dikelompokkan menjadi dua bagian pokok yaitu gaya gempa (intensitas dan arah getaran) serta kondisi tanah dan lingkungan (properti tanah, kondisi topografi, muka air tanah, dsb).

\section{Parameter-Parameter yang Mempengaruhi Potensi Likuifaksi Pada Tanah}

Parameter-parameter yang mempengaruhi potensi likuifaksi antara lain adalah:

\section{Tegangan Vertikal Total ( $\sigma \mathrm{v})$}

Tegangan vertikal total dapat dihitung dengan rumus :

$$
\sigma v=\Sigma(\gamma \cdot \mathrm{H})
$$

Dengan $\sigma v=$ Tegangan Vertikal Total (kN/m2 ), $\gamma=$ Berat isi lapisan tanah (kN/m3 ), H = Tebal lapisan tanah (m)

\section{Faktor Reduksi (CD)}

Faktor reduksi merupakan nilai yang dapat mempengaruhi tegangan di dalam tanah. Semakin jauh kedalaman tanah maka faktor reduksi akan semakin kecil.faktor reduksi dapat dilihat pada diagram reduksi tegangan geser dengan faktor CD (Seed,dan Idriss.1971)

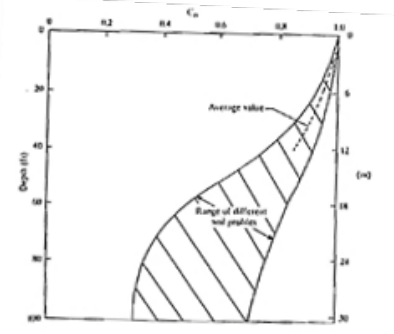

Metode-Meto Gambar 2.Diagram reduksi tegangan geser dengan faktor CD (Seed,dan Idriss.1971) 
Pada dasarnya, analisis potensi likuifaksi adalah mencari 2 parameter utama, yaitu : Cyclic Stress Ratio (CSR) yang merupakan tegangan siklik yang terjadi akibat gempa dibagi dengan tegangan efektif dan Cyclic Resistance Ratio (CRR) yang merupakan ketahanan tanah untuk menahan likuifaksi

\section{Cyclic Stress Ratio (CSR)}

Cyclic Stress Ratio adalah tegangan siklik yang terjadi akibat gempa dibagi dengan tegangan efektif. Seed dan Idriss (1971) memformulasikan persamaan untuk rasio tegangan siklik (CSR), yaitu :

$$
\operatorname{CSR}=\frac{\tau_{a v g}}{\sigma_{v 0 \prime}}=0.65\left(\frac{a_{\max }}{g}\right)\left(\frac{\sigma_{v o}}{\sigma_{v 0 \prime}}\right) C D
$$

Dengan $\tau_{\text {avg }}=$ cyclic shear stress rata - rata, $\sigma_{\mathrm{vo}}=$ overburden stress, a $\max =$ Percepatan Gempa Dasar, $\sigma_{\mathrm{vo}}=$ total vertical stress, $\sigma_{\mathrm{vo}^{\prime}}=$ vertical stress effective, $\mathrm{CD}=$ Faktor reduksi stress, CSR $=$ Cylic Strees Ratio

Menurut metode yang disarankan oleh Seed dan Idriss, tegangan geser yang menyebabkan likuifaksi dapat dihitung dari tegangan geser siklik $\tau_{\text {avg }}$ yang dihasilkan pada setiap titik pada lapisan tanah, dan dinyatakan dengan rumus :

$$
T_{a v}=0.65 C D\left[\frac{\gamma D}{g}\right] \times a_{\max }
$$

Dengan = berat satuan total, $\mathrm{D}=$ kedalaman, $\mathrm{g}=$ percepatan gravitasi

\section{Cyclic Resistance Ratio (CRR)}

Cyclic Resistance Ratio (CRR) yang merupakan ketahanan tanah untuk menahan likuifaksi. Berikut adalah faktorfaktor yang dibutuhkan.

\section{Mencari N' koreksi}

Setelah menghitung nilai tegangan efektif tanah, untuk menghitung ketahanan tanah terhadap likuifaksi maka nilai N' koreksi dengan mencari Faktor $\mathrm{C}_{\mathrm{N}}$ untuk mengkoreksi nilai SPT $\mathrm{C}_{\mathrm{N}}$ dapat dicari dengan rumus berikut:

$$
C_{N}=\sqrt{\frac{1}{\sigma_{v o l}}}
$$

Dengan $\mathrm{N}=$ Nilai N-SPT lapangan., $\mathrm{C}_{\mathrm{N}}=$ faktor koreksi untuk konversi berat sendiri tanah (overburden pressure) ke tekanan 1 ton/ft2.,

\section{Mencari Ratio $\frac{T_{h}}{\sigma_{v}}$}

Setelah mengoreksi nilai N-SPT lapangan maka kita mencari ratio $\frac{T_{h}}{\sigma_{v}}$ dengan melihat parameter nilai N-SPT korelasi dan magnitude gempa dengan menggunakan Diagram (Seed,1979)

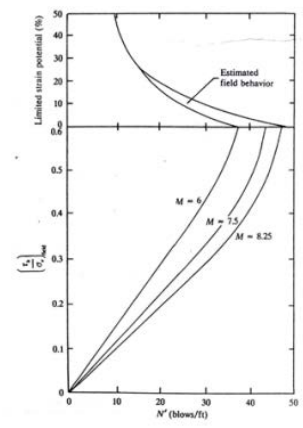

Gambar 3. Korelasi N' dan M dengan $\frac{T_{h}}{\sigma_{v}}($ Seed,1979)

\section{Menentukan Potensi Likuifaksi}

Setelah mendapatkan ratio $\frac{T_{h}}{\sigma_{v o}}$ maka ditentukan nilai $T_{h}$ dengan menggunakan tekanan efektif tanah yang dapat dibandingkan dengan nilai $\tau_{\text {avg. }}$ Jika nilai $\tau_{\text {avg }}>T_{h}$ maka dapat disimpulkan bahwa terjadi likuifaksi.

\section{Solusi Likuifaksi yang dapat diaplikasikan oleh masyarakat}


Setelah mengetahui potensi likuifaksi didaerah Palu maka kita mencari beberapa solusi yang dapat diaplikasikan oleh masyarakat Palu. Beberapa solusi yang akan dibahas antara lain adalah micropiles bambu, pemasangan pipa piezometer, pembuatan sumur resapan, dan penanaman tanaman Bambu dan Baobab (Adansonia digitata).

\section{Micropile Bambu ( Salauwe,R., Manoppo,F.J., Monintja,S. 2015)}

Tiang bambu sebagai pemodelan micro pile merupakan salah satu jenis tiang pancang yang merupakan bagian dari konstruksi yang dapat memperkuat struktur tanah seperti tanah likuifaksi. Fungsi bambu sebagai tiang pancang ini untuk mentransfer beban-beban dari atas kelapisan tanah. Bentuk distribusi beban dapat berbentuk beban vertikal melalui dinding tiang Perhitungan micropiles bambu dimulai denan perhitungan daya dukung tanah sebelum dan saat terjadi likuifaksi. Perhitungan dari daya dukung ini menggunakan persamaan Vesic yang menyatakan bahwa tanah pasir lepas akan terjadi likuifaksi apabila tanah itu mengalami getaran, maka sudut geser dalam akan berkurang dari sudut geser dalam sebelum terjadi likuifaksi.

$$
\mathrm{q}_{\mathrm{u}}=\mathrm{P}_{\mathrm{o}} \times \mathrm{N}_{\mathrm{q}} \times \mathrm{S}_{\mathrm{q}} \times \mathrm{d}_{\mathrm{q}} \times \mathrm{i}_{\mathrm{q}} \times \mathrm{g}_{\mathrm{q}} \times \mathrm{b}_{\mathrm{q}}
$$

Dengan $\mathrm{P}_{\mathrm{o}}=$ Tegangan overburden, $\mathrm{N}_{\mathrm{q}}=$ Faktor Kapasitas Daya Dukung, $\mathrm{S}_{\mathrm{q}}=$ Faktor Bentuk Fondasi, $\mathrm{d}_{\mathrm{q}}=$ Faktor Kedalaman, $\mathrm{i}_{\mathrm{q}}=$ Faktor Kemiringan Beban, $\mathrm{g}_{\mathrm{q}}=$ Faktor Kemiringan Permukaan, $\mathrm{b}_{\mathrm{q}}=$ Faktor Kemiringan Dasar

\section{Kapasitas Daya Dukung Tanah Dengan bambu Sebagai micropile}

Kapasitas daya dukung tiang merupakan jumlah dari kapasitas akhir atau perlawanan ujung dengan perlawanan selimut tiang. Untuk menghitung daya dukung pondasi tiang pancang berdasarkan data SPT dapat digunakan Metode Mayerhof dan Luciano Decourt, adapun rumus yang digunakan antara lain :

Daya dukung ujung pondasi tiang dengan Metode Meyerhof :

$$
Q_{p}=40 \times N_{S P T} \times A_{P}
$$

Tahanan geser selimut tiang Metode Meyerhof :

$$
Q_{S}=0.2 \times N_{S P T} \times P \times L_{i}
$$

Dengan $\mathrm{N}_{\mathrm{SPT}}=$ Nilai SPT, $\mathrm{A}_{\mathrm{p}}=$ Luas Ujung Tiang $\left(\mathrm{m}^{2}\right), \mathrm{P}=$ Keliling Tiang $(\mathrm{m}), \mathrm{L}_{\mathrm{i}} \quad=$ Tebal Lapisan Tanah $(\mathrm{m})$

Daya dukung ujung pondasi tiang dengan Metode Luciano Decourt :

$$
\left.\mathrm{Q}_{\mathrm{P}}=\overline{\mathrm{N}} \times \mathrm{K} \times A_{p} \text { dalam (ton } / \mathrm{m}^{2}\right)
$$

Tahanan geser selimut tiang Metode Luciano Decourt :

$$
\mathrm{Q}_{\mathrm{s}}=\left(\frac{N_{s}}{3}+1\right) \times A_{s} \text { dalam }\left(\operatorname{ton} / \mathrm{m}^{2}\right)
$$

Dengan $\overline{\mathrm{N}}=$ Nilai rata-rata SPT, $\mathrm{A}_{\mathrm{p}}=$ Luas Ujung Tiang $\left(\mathrm{m}^{2}\right), \mathrm{A}_{\mathrm{s}}=$ Luas Selimut Tiang $\left(\mathrm{m}^{2}\right), \mathrm{N}_{\mathrm{s}}=3 \leq \mathrm{N} \leq 50$, $\mathrm{K}=$ Koefisien Karakteristik Tanah (ton $/ \mathrm{m}^{2}$ )

\section{Analisis Penurunan Tanah Sebelum, Sesudah dan Dengan bambu Sebagai micropile}

Jika tanah Elastis (Bowles, 1983) besar penurunan dapat ditentukan dengan persamaan :

$$
S e=q_{u} x\left(\alpha B^{\prime}\right) \times \frac{1-\mu s^{2}}{E s} \times \text { Is } x \text { If }
$$

Dengan $\mathrm{q}_{\mathrm{u}}$ = daya dukung tanah, $\mu s=$ Poisson's ratio tanah, $\mathrm{E}_{\mathrm{s}} \quad=$ Modulus Elastisitas Tanah, B' = B/2 untuk pusat fondasi, Is = faktor bentuk, If = faktor kedalaman.

Penurunan ini biasanya terjadi akibat beban bangunan yang didistribusikan terhadap tiang dan sampai ke dalam lapisan tanah, sehingga dapat dihitung penurunan tiang (micropile) berdasarkan persamaan dibawah ini.

$$
S 1=\frac{\left(Q_{P}+\alpha Q_{S}\right) L}{A_{P} x E_{P}}
$$




$$
\begin{gathered}
S 2=\frac{\left(q_{w P} D\right)}{E_{S}} \times 1-\mu s^{2} \times I_{w p} \\
S 3=\frac{Q_{W S}}{P L} \times \frac{D}{E_{S}}\left(1-\mu s^{2}\right) \times I_{w s}
\end{gathered}
$$

Dengan, S1 =Penurunan batang tiang , S2 = Penurunan tiang akibat beban diujung tiang , S3 =Penurunan tiang akibat beban tersalurkan sepanjang tiang, $\mathrm{L}=$ Panjang yang tertanam, $\mathrm{E}_{\mathrm{p}}=$ Modulus Elastisitas Tiang, $\mathrm{Q}_{\mathrm{wp}}=$ Beban titik per satuan luas ujung tiang, $\mathrm{D}=$ Lebar atau diameter tiang, $\mathrm{I}_{\mathrm{wp}}=$ Faktor Pengaruh, $\mathrm{L}=$ Panjang tiang yang tertanam, $\mathrm{I}_{\mathrm{ws}}=$ Faktor Pengaruh

\section{Pipa Piezometer dan Sumur Resapan}

Salah satu penyebab utama dari peristiwa likuifaksi adalah nilai tekanan air yang tiba-tiba meningkat dan menekan ke segala arah terutama ke atas, akibat terjadinya goncangan akibat gempa di Palu. Dengan pemasangan pipa piezometer dan sumur resapan diharapkan peningkatan tekanan air pori akibat guncangan dapat keluar melalui pipa piezometer dan sumur resapan yang sudah di pasang sehingga tekanan air pori dapat berkurang dan direkayasa. Perhitungan dimulai dengan tegangan vertikal total dan tegangan vertikal efektif . Setelah mendapatkan tegangan vertikal total dan tegangan vertikal efektif maka dapat ditentukan tekanan air pori yang selanjutnya dianalisis untuk mendapatkan tekanan uplift 1 $\mathrm{m}^{2}$. Setelah didapatkan maka kita menghitung tekanan uplift yang dialami pipa dengan rumus. Kemudian dapat dianalisis tekanan pipa dan sumur dengan menggunakan rumus.

$$
\begin{gathered}
\text { Tekanan uplift pipa }=\frac{\text { tekanan uplift }}{\text { luas permukaan pipa }} \\
\mathrm{P}_{\text {pipa }}=\rho \cdot g \cdot h \\
\text { Jumlah pipa }=\frac{\text { tekanan uplift pipa }}{\text { Tekanan pipa }}
\end{gathered}
$$

Dengan, $\rho$ = Berat jenis Air, $\mathrm{g}=$ percepatan gravitasi, $\mathrm{h}=$ kedalaman

\section{Akar Tanaman}

Secara umum tanah terdiri dari 3 komposisi yaitu air,udara, dan tanah. 3 komposisi itu yang membentuk tanah secara

\begin{tabular}{|c|c|c|c|c|}
\hline \multirow[b]{2}{*}{ type of soil } & \multirow[b]{2}{*}{$\begin{array}{l}\mathrm{SPT}, \\
N\end{array}$} & \multirow[b]{2}{*}{$\begin{array}{c}\text { relative } \\
\text { density, } \\
\qquad D_{r}\end{array}$} & \multicolumn{2}{|c|}{$\begin{array}{l}\text { angle of internal } \\
\text { friction, } \phi\end{array}$} \\
\hline & & & $\begin{array}{c}\text { Peck, et al., } \\
1974\end{array}$ & $\begin{array}{c}\text { Meyerhof, } \\
1956\end{array}$ \\
\hline very lowe satxi & $<4$ & $<0.02$ & $<29$ & $<30$ \\
\hline loose sand & $4-10$ & $0.2-0.4$ & $29-30$ & $30-35$ \\
\hline medium saxd & $10-30$ & $0.4-0.6$ & $30-36$ & $35-40$ \\
\hline dense sard & $30-50$ & $0.6-0.8$ & $36-41$ & $40-45$ \\
\hline very derse sarxi & $>50$ & $>0.8$ & $>41$ & $>45$ \\
\hline
\end{tabular}
keseluruhan. Penanaman pohon mampu menguragi volume udara dalam tanah sehingga rongga-rongga udara berkurang dan juga mampu mengikat tanah sehingga Relative Density tanah meningkat.Berikut adalah tabel yang menjadi korelasi yang dapat digunakan untuk perhitungan akar tanaman.

Tabel 1. Tabel Hubungan SPT Relative Density,dan sudut geser di tanah berpasir. (Hsai-Yang.1991)

Berikut adalah ilustrasi morfologi akar tanaman bambu dan baobab secara fisik
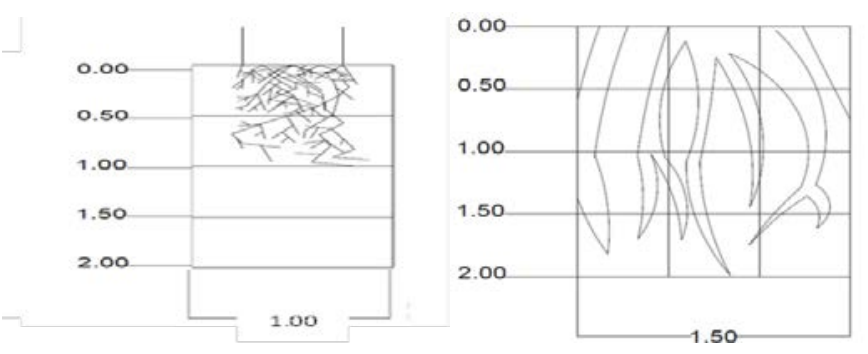

Gambar 4 Ilustrasi Gambar Akar Tanaman Bambu (kiri) dan Baobab (kanan) 
Sementara untuk menghitung menghitung Void Ratio baru setelah melihat morfologi akar tanaman dengan asumsi reduksi akar bambu 0,15 dan baobab 0,1. bisa menggunakan rumus pada buku (Braja M.Das, 1995)

$$
D_{r}=\frac{e_{\text {maks }}-e}{e_{\text {maks }}-e_{\min }}
$$

Dengan, $\mathrm{D}_{\mathrm{r}}=$ kerapatan Relatif, $\mathrm{e}=$ angka pori lapangan, $\mathrm{e}_{\mathrm{maks}}=$ angka pori dalam keadaan paling lepas $\mathrm{e}_{\mathrm{min}}=$ angka pori dalam keadaan paling padat

Tabel 2. Tabel nilai angka pori, kadar air dan berat volume kering untuk beberapa tipe tanah yang masih dalam keadaan asli (Braja M.Das, 1995)

\begin{tabular}{|c|c|c|c|c|}
\hline \multirow[t]{2}{*}{ Tipe Tanah } & \multirow{2}{*}{$\begin{array}{l}\text { Angka } \\
\text { Pori }\end{array}$} & \multirow{2}{*}{$\begin{array}{l}\text { Kadar Air dalam } \\
\text { Keadaan Jenuh }\end{array}$} & \multicolumn{2}{|c|}{ Berat Volume Kering } \\
\hline & & & $l b / f t^{3}$ & $k N / m^{3}$ \\
\hline Pasir Lepas dengan Butiran Seragam & 0.80 & 30 & 92 & 14.5 \\
\hline Pasir Padat dengan Butiran Seragam & 0.45 & 16 & 115 & 18 \\
\hline Pasir Berlanau yang Lepas Butiran Bersudut & 0.65 & 25 & 102 & 16 \\
\hline Pasir Berlanau yang Padat Butiran Bersudut & 0.40 & 15 & 121 & 19 \\
\hline Lempung kaku & 0.60 & 21 & 108 & 17 \\
\hline Lempung lembek & $0.9-1.4$ & $30-50$ & $73-93$ & $11.5-14.5$ \\
\hline Tanah & 0.90 & 25 & 86 & 13.5 \\
\hline Lempung organik Lembek & $2.5-3.2$ & $90-120$ & $38-51$ & $6-8$ \\
\hline Glacial till & 0.30 & 10 & 134 & 21 \\
\hline
\end{tabular}

\section{METODOLOGI PENELITIAN}

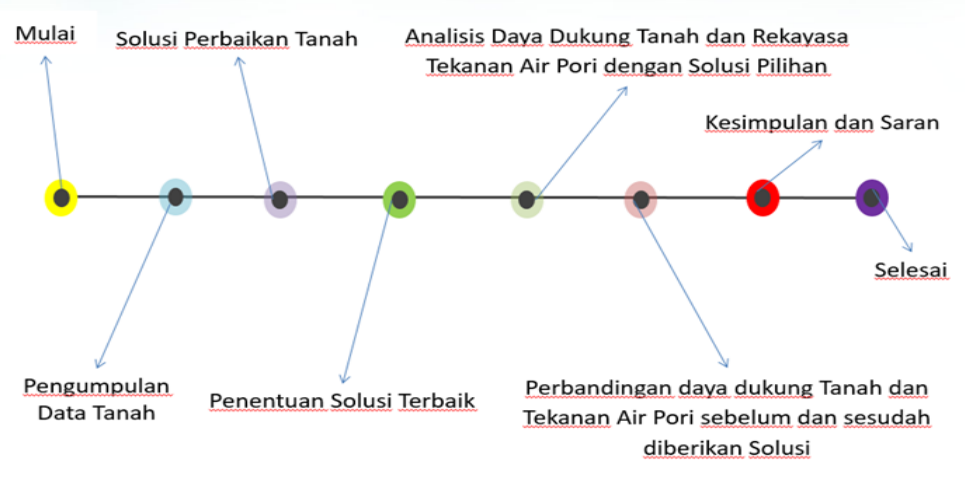

Gambar 5. Diagram Alir Penelitian.

\section{HASIL PENELITIAN DAN PEMBAHASAN}

\section{Perhitungan Potensi Likuifaksi}

Dengan menggunakan rumus untuk menentukan nilai $T_{h}$ dengan menggunakan tekanan efektif tanah yang dapat dibandingkan dengan nilai $\tau_{\text {avg }}$ yang merupakan tegangan siklik yang terjadi akibat gempa, maka didapatkan hasil seperti pada tabel dibawah ini. Jika nilai $\tau_{\text {avg }}>T_{h}$ maka dapat disimpulkan bahwa terjadi likuifaksi. 
Tabel 3. Hasil Perhitungan Likuifaksi Sulawesi 1 (S-1), Sulawesi 2 (S-2),dan Sulawesi 3 (S-3)

\begin{tabular}{|c|c|c|c|c|c|c|c|c|c|c|c|c|}
\hline \multirow[t]{2}{*}{ Depth } & \multicolumn{3}{|c|}{ NSPT } & \multicolumn{3}{|c|}{$T_{h}$} & \multicolumn{3}{|c|}{$\tau_{\text {avg }}$} & \multicolumn{3}{|c|}{ Potensi Likuifaksi } \\
\hline & S - 1 & $S-2$ & $S-3$ & S - 1 & $S-2$ & $S-3$ & S - 1 & $S-2$ & $S-3$ & S - 1 & S - 2 & $S-3$ \\
\hline 1.5 & 12 & 15 & 15 & 0.61 & 0.58 & 0.80 & 0.35 & 0.35 & 0.35 & TIDAK & TIDAK & TIDAK \\
\hline 3 & 2 & 5 & 2 & 0.12 & 0.31 & 0.13 & 0.69 & 0.69 & 0.69 & YA & YA & YA \\
\hline 4.5 & 3 & 2 & 1 & 0.20 & 0.10 & 0.07 & 1.02 & 1.02 & 1.02 & YA & YA & YA \\
\hline 6 & 2 & 5 & 35 & 0.12 & 0.37 & 2.87 & 1.35 & 1.35 & 1.35 & YA & YA & TIDAK \\
\hline 7.5 & 12 & 7 & & 0.97 & 0.60 & & 1.67 & 1.67 & & YA & YA & \\
\hline 9 & 5 & 5 & & 0.43 & 0.41 & & 1.98 & 1.87 & & YA & YA & \\
\hline 10.5 & 17 & & & 1.67 & & & 2.29 & & & YA & & \\
\hline
\end{tabular}

\section{Solusi Likuifaksi yang dapat diaplikasikan oleh masyarakat}

Berdasarkan perhitungan diatas mengenai potensi likuifaksi, dapat disimpulkan bahwa daerah Palu ditermasuk dalam daerah likuifaksi. Dari 3 titik tersebut berpotensi likuifaksi oleh sebab itu dilanjutkan dengan perhitungan perbaikan tanah yang diusulkan yaitu micropiles bambu, pemasangan pipa piezometer, pembuatan sumur resapan, dan penanaman tanaman Bambu dan Baobab (Adansonia digitata.)

\section{Micropile Bambu}

Perhitungan micropiles bambu dimulai dengan perhitungan daya dukung tanah sebelum dan saat terjadi likuifaksi. Perhitungan dari daya dukung ini menggunakan persamaan Vesic yang menyatakan bahwa tanah pasir lepas akan terjadi likuifaksi apabila tanah itu mengalami getaran, maka sudut geser dalam akan berkurang dari sudut geser dalam sebelum terjadi likuifaksi yang dapat dilihat pada table dibawah ini.

Tabel 4.Perhitungan Daya Dukung Tanah Sebelum dan Saat Terjadi Likuifaksi (metode Vesic)

\begin{tabular}{ccccc}
\hline $\begin{array}{c}\text { Depth } \\
\text { (m) }\end{array}$ & \multicolumn{2}{c}{ Sebelum Likuifaksi } & \multicolumn{2}{c}{ Saat Likuifaksi } \\
\cline { 2 - 5 } & $\begin{array}{c}Q_{u} \\
\left(\mathrm{kN} / \mathrm{m}^{2}\right)\end{array}$ & $\begin{array}{c}Q_{u} \text { All } \\
\left(\mathrm{kN} / \mathrm{m}^{2}\right)\end{array}$ & $\begin{array}{c}Q_{u} \\
\left(\mathrm{kN} / \mathrm{m}^{2}\right)\end{array}$ & $\begin{array}{c}Q_{u} \text { All } \\
\left(\mathrm{kN} / \mathrm{m}^{2}\right)\end{array}$ \\
\hline $\mathbf{1 . 5}$ & 65.39 & 21.80 & 55.89 & 18.63 \\
\hline $\mathbf{3}$ & 147.84 & 49.28 & 126.36 & 42.12 \\
\hline $\mathbf{4 . 5}$ & 247.35 & 82.45 & 211.41 & 70.47 \\
\hline $\mathbf{6}$ & 363.92 & 121.31 & 311.04 & 103.68 \\
\hline $\mathbf{7 . 5}$ & 497.54 & 165.85 & 425.25 & 141.75 \\
\hline $\mathbf{9}$ & 648.23 & 216.08 & 554.04 & 184.68 \\
\hline $\mathbf{1 0 . 5}$ & 815.97 & 271.99 & 697.41 & 232.47 \\
\hline
\end{tabular}

Setelah menganalisis daya dukung tanah sebelum dan saat terjadi likuifaksi maka dibandingkan setelah menggunakan micropile bambu dengan metode Meyerhof dan Luciano Decourt. Hasil perhitungan dapat dilihat pada tabel 5 . 
Tabel 5. Perhitungan Daya Dukung Fondasi (Meyerhof dan Luciano Decourt)

\begin{tabular}{cccc}
\hline $\begin{array}{c}\text { Kedalaman } \\
(\mathbf{m})\end{array}$ & $\begin{array}{c}Q_{u} \text { All } \\
\left(\mathrm{kN} / \mathrm{m}^{2}\right)\end{array}$ & Metode & Kawasan \\
\cline { 1 - 2 } $\mathbf{7 . 5}$ & 56.54 & Meyerhof & SULAWESI 1 \\
\cline { 1 - 2 } $\mathbf{7 . 5}$ & 45.20 & Luciano Decourt & \\
\hline $\mathbf{7 . 5}$ & 32.98 & Meyerhof & SULAWESI 2 \\
\cline { 1 - 2 } $\mathbf{6}$ & 42.36 & Luciano Decourt & \\
\hline $\mathbf{6}$ & 148.43 & Meyerhof & SULAWESI 3 \\
\hline
\end{tabular}

Kemudian dilakukan analisis terhadap penurunan tanah sebelum dan saat terjadi likuifaksi (Bowles 1983) maka dibandingkan setelah menggunakan micropile bambu dengan metode Meyerhof dan Luciano Decourt. hasil perhitungan dapat dilihat pada tabel 6.

Tabel 6.Perbandingan Penurunan Tanah

\begin{tabular}{|c|c|c|}
\hline $\begin{array}{c}\text { Penurunan } \\
\text { Tanah }\end{array}$ & Metode & Kawasan \\
\hline 0.63 & Sebelum Likuifaksi & SULAWESI 1 \\
\hline 0.54 & Setelah Likuifaksi & \\
\hline 0.46 & Meyerhof & \\
\hline 0.21 & Luciano Decourt & \\
\hline 0.46 & Sebelum Likuifaksi & SULAWESI 2 \\
\hline 0.39 & Setelah Likuifaksi & \\
\hline 0.11 & Meyerhof & \\
\hline 0.20 & Luciano Decourt & \\
\hline 0.28 & Sebelum Likuifaksi & SULAWESI 3 \\
\hline 0.24 & Setelah Likuifaksi & \\
\hline 0.14 & Meyerhof & \\
\hline 0.23 & Luciano Decourt & \\
\hline
\end{tabular}

\section{Pipa Piezometer dan Sumur Resapan}

Dalam pemasangan pipa piezometer yang dipasang berdiameter 6 inch,dan sumur resapan dengan diameter $1 \mathrm{~m}$. Dengan mengacu pada landasan teori diatas maka dapat ditentukan jumlah pipa dan sumur yang harus dipasang pada ketiga lokasi tersebut dengan nilai tekanan air pori yang besar. Jumlah pemasangan pipa dilihat pada tabel 7. 
Tabel 7. Jumlah pipa dan sumur yang dipasang di Sulawesi 1, Sulawesi 2, dan Sulawesi 3

\begin{tabular}{|c|c|c|c|c|}
\hline $\begin{array}{l}\text { Depth } \\
\text { (m) }\end{array}$ & $\begin{array}{c}\text { Pore Pressure Test } \\
\left(\mathrm{Ton} / \mathrm{m}^{2}\right)\end{array}$ & $\begin{array}{l}\text { Jumlah } \\
\text { Pipa }\end{array}$ & $\begin{array}{l}\text { Jumlah } \\
\text { Sumur }\end{array}$ & Kawasan \\
\hline 6.00 & 4.04 & 4 & 1 & \multirow{3}{*}{$\begin{array}{c}\text { Sulawesi } \\
1\end{array}$} \\
\hline 8.00 & 2.02 & 4 & 1 & \\
\hline 9.50 & 2.02 & 4 & 1 & \\
\hline 4.00 & 15.15 & 18 & 1 & \multirow{3}{*}{$\begin{array}{c}\text { Sulawesi } \\
2\end{array}$} \\
\hline 4.50 & 20.20 & 21 & 1 & \\
\hline 7.50 & 25.25 & 16 & 1 & \\
\hline 5.00 & 10.10 & 10 & 1 & \multirow{3}{*}{$\begin{array}{c}\text { Sulawesi } \\
3\end{array}$} \\
\hline 5.50 & 5.05 & 5 & 1 & \\
\hline 6.00 & 5.05 & 4 & 1 & \\
\hline
\end{tabular}

\section{Akar Bambu dan Baobab (Adansonia digitata).}

Perhitungan peningkatan nilai Relative Density tanah akibat void ratio yang terisi dengan akar tanaman dapat dilihat pada tabel 8.

Tabel 8. Peningkatan Relative Density di Sulawesi 1, Sulawesi 2, dan Sulawesi 3.

\begin{tabular}{|c|c|c|c|c|c|c|c|c|c|}
\hline \multirow{2}{*}{$\begin{array}{l}\text { Depth } \\
\text { (m) }\end{array}$} & \multirow[t]{2}{*}{ NSPT } & \multirow{2}{*}{$\begin{array}{l}\text { Relative } \\
\text { Density }\end{array}$} & \multicolumn{3}{|c|}{ Tanaman Baobab } & \multicolumn{3}{|c|}{ BAMBU } & \multirow[t]{2}{*}{ Kawasan } \\
\hline & & & $\begin{array}{l}\text { Angka } \\
\text { Pori }\end{array}$ & $\begin{array}{c}\text { Peningkatan } \\
\text { Angka Pori }\end{array}$ & $\begin{array}{c}\text { Relative } \\
\text { Density Baru }\end{array}$ & $\begin{array}{l}\text { Angka } \\
\text { Pori }\end{array}$ & $\begin{array}{c}\text { Peningkatan } \\
\text { Angka Pori }\end{array}$ & $\begin{array}{c}\text { Relative } \\
\text { Density Baru }\end{array}$ & \\
\hline 0.50 & 35 & 0.58 & 0.57 & 0.10 & 0.83 & 0.57 & 0.15 & 0.96 & \multirow{4}{*}{$\begin{array}{c}\text { Sulawesi } \\
1\end{array}$} \\
\hline 1.00 & 7 & 0.14 & 0.74 & 0.08 & 0.22 & 0.74 & 0.10 & 0.39 & \\
\hline 1.50 & 12 & 0.24 & 0.70 & 0.50 & 0.74 & - & - & - & \\
\hline 2.00 & 5 & 0.10 & 0.76 & 0.25 & 0.35 & - & - & - & \\
\hline 0.50 & 17 & 0.28 & 0.69 & 0.10 & 0.38 & 0.69 & 0.15 & 0.66 & \multirow{4}{*}{$\begin{array}{c}\text { Sulawesi } \\
2\end{array}$} \\
\hline 1.00 & 2 & 0.04 & 0.78 & 0.08 & 0.12 & 0.78 & 0.10 & 0.29 & \\
\hline 1.50 & 15 & 0.30 & 0.68 & 0.50 & 0.80 & - & - & - & \\
\hline 2.00 & 5 & 0.10 & 0.76 & 0.25 & 0.35 & - & - & - & \\
\hline 0.50 & 2 & 0.03 & 0.79 & 0.10 & 0.13 & 0.79 & 0.15 & 0.41 & \multirow{4}{*}{$\begin{array}{c}\text { Sulawesi } \\
3\end{array}$} \\
\hline 1.00 & 2 & 0.04 & 0.78 & 0.08 & 0.12 & 0.78 & 0.10 & 0.29 & \\
\hline 1.50 & 15 & 0.30 & 0.68 & 0.50 & 0.80 & - & - & - & \\
\hline 2.00 & 2 & 0.04 & 0.78 & 0.25 & 0.29 & - & - & - & \\
\hline
\end{tabular}




\section{KESIMPULAN}

Berdasarkan hasil penelitian dan pembahasan, ada beberapa hal yang disimpulkan berdasarkan tujuan penelitian. Adapun kesimpulan yang diperoleh dapat dijabarkan sebagai berikut:

1. Potensi likuifaksi dan pada lokasi 1 dan 2 potensi likuifaksinya masih terus terjadi hingga lebih dari kedalaman $8.5 \mathrm{~m}$, sementara di lokasi Sulawesi 3 potensi likuifaksi hanya sampai di kedalaman $6 \mathrm{~m}$.

2. Daya dukung Tanah menjadi meningkat hingga 2 kali setelah menggunakan micropiles.

3. Penurunan tanah setelah menggunakan micropiles bambu menurun hingga $18 \%$ dari sebelumnya

4. Penggunaan pipa efisien untuk darah sulawesi 1 adalah 4 untuk sulawesi 2 adalah 18 dan sulawesi 3 adalah 7 , sementara 1 sumur resapan di setiap daerah.

5. Baobab dan Bambu mampu mengurangi void ratio hingga $10-15 \%$

\section{SARAN}

Berdasarkan hasil penelitian yang dilakukan, maka terdapat beberapa saran yang dapat dilakukan sebagai bentuk mitigasi bencana likuifaksi selanjutnya.

1. Solusi diusulkan hanya mengurangi kerusakan likuifaksi secara mikro tidak padat menghilangkan potensi likuifaksi secara masif.

2. Pada perhitungan akar tanaman perlu dilakukan penelitian dan uji laboratorium untuk mendapatkan hasil yang lebih optimal, karena perhitungaan saya mengenai akar tanaman hanya dengan menggunakan pendekatan morfologi akar.

3. Solusi pipa dan sumur kurang relevan jika tekanan air pori terlalu besar.

\section{DAFTAR PUSTAKA}

Bowles. Joseph. E. 1983. Analisa dan Desain Pondasi Jilid 1 Edisi ke 3. Jakarta : Erlangga

Braja, M.Das.1995.Mekanika Tanah (Prinsip-Prinsip Rekayasa Geoteknis Jilid 1). Jakarat: Erlangga.

Hsai-Yang Fang,1991,Foundation Engineering Handbook. Springer US

Peck Ralph. B, Thornburn Thomas H, Hansen Walter E.Teknik Pondasi. Yogyakarta: Gadjah Mada University Press

Salauwe,R., Manoppo,F.J., Monintja,S. (2015) “Analisa Perkuatan Tanah dengan Bambu Sebagai Micropile Pada Tanah Liquefaction (Proyek PLTU Manokwari).”Jurnal Ilmiah Media Engineering Vol. 5 No.2, September 2015 (351-361).

Seed, H. B. (1979), "Soil Liquefaction and Cyclic Mobility Evaluation for Level Ground During Earthquakes," J. Geotech. Engng. Div., ASCE, Vol. 105, No. GT2, Feb., pp. 201-255.

Seed, H.B. and Idriss, I.M. (1971) Simplified Procedure for Evaluating Soil Liquefaction Potential. Journal of the Soil Mechanics and Foundations Division, ASCE 97, SM9, 1249-1273.

Seed, H. B., Makdisi, F., Idriss, I. M., and Lee, K. L. (1975). The slides in the San Fernando Dams during the earthquake of February, 9, 1971. J. Geotech. Eng. Div. 101:7, 651-688

SNI 03-2847-2002. 2002. Tata Cara Perencanaan Gempa Untuk Bangunan Gedung. Badan Standarisasi Nasional. Jakarta

Towhata, I. (2008) Geotechnical Earthquake Engineering. Springer Science \& Business Media, Berlin.

Wang, J.G and Law, K.T (1994) Siting in Earthquake Zones, Balkema, Rotterdam. 